\title{
Perangkat Pembelajaran Inkuiri Terbimbing Berbantuan Handout Berbasis Potensi Lokal Hutan Mangrove untuk Meningkatkan Kemampuan Berpikir Kritis dan Sikap Peduli Lingkungan
}

\author{
Endah Sulistyowati ${ }^{1}$, Fatchur Rohman ${ }^{1}$, Ibrohim ${ }^{1}$ \\ ${ }^{1}$ Pendidikan Biologi-Universitas Negeri Malang
}

\section{INFO ARTIKEL}

Riwayat Artikel:

Diterima: 20-08-2019

Disetujui: 17-03-2020

\section{Kata kunci:}

guided inquiry;

critical thinking skills;

attitude of caring for the

environment;

inkuiri terbimbing,

kemampuan berpikir kritis;

sikap peduli lingkungan

\author{
Alamat Korespondensi: \\ Endah Sulistyowati \\ Pendidikan Biologi \\ Universitas Negeri Malang \\ Jalan Semarang 5 Malang \\ e-mail: end.sulist@gmail.com
}

\section{ABSTRAK}

\begin{abstract}
The study was conducted to produce a guided inquiry learning model on ecosystem material and environment pollution aided by handout based on the local potential of mangrove forest Pantai Duta to improve critical thinking skills and environmental awareness. The type of research is development research with reference to the ADDIE development model. The research sample of 64 students of $7^{\text {th }}$ class SMPN 2 Paiton. Research data collection using validation sheets, questions about critical thinking skills, and questionnaires. The result of the study state that the guided inquiry learning tool is valid and practical, and can improve critical thinking skills and environmental care attitudes.
\end{abstract}

\begin{abstract}
Abstrak: Penelitian dilakukan untuk menghasillkan perangkat pembelajaran inkuiri terbimbing materi ekosistem dan pencemaran lingkungan berbantuan handout berbasis potensi lokal hutan mangrove Pantai Duta untuk meningkatkan kemampuan berpikir kritis dan sikap peduli lingkungan. Jenis penelitian ini merupakan penelitian pengembangan dengan mengacu pada model pengembangan ADDIE. Sampel penelitian sebanyak 64 siswa kelas VII SMPN 2 Paiton. Pengumpulan data penelitian menggunakan lembar validasi, soal kemampuan berpikir kritis, dan angket. Hasil penelitian menyatakan bahwa perangkat pembelajaran inkuiri terbimbing valid dan praktis, serta dapat meningkatkan kemampuan berpikir kritis dan sikap peduli lingkungan.
\end{abstract}

Proses pembelajaran seharusnya berlangsung secara interaktif dan inspiratif (Permendikbud, 2016) sehingga siswa dapat mengembangkan aktivitas dan kreativitasnya (Mulyasa, 2009). Seharusnya pembelajaran tidak hanya sekedar menghafal fakta atau informasi, tetapi terjadi proses berpengalaman (Sanjaya, 2010), sehingga terbentuk manusia terdidik yang mempunyai kemampuan untuk memahami dan menyesuaikan diri terhadap lingkungannya, mampu menjadi pelaku perubahan serta mampu mengantisipasi sesuatu yang akan terjadi (Hatimah, 2006). Pembelajaran yang hanya berorientasi pada penguasaan materi terbukti berhasil hanya dalam kompetisi mengingat dalam jangka pendek (Faridah, 2012). Sejalan dengan itu, adanya sumber belajar juga dapat meningkatkan aktivitas dan kreativitas belajar (Mulyasa, 2013). Guru selain berperan sebagai fasilitator juga berperan penting sebagai pendesain sumber belajar (Permendiknas, 2006). Sumber belajar berbasis potensi lokal daerah diharapkan mampu mendorong siswa lebih memahami materi karena contoh yang dihadirkan adalah nyata ada di sekitar mereka. Melalui potensi lokal siswa dapat diajak untuk melakukan pengamatan ekosistem di lingkungan sekolah atau luar sekolah (Situmorang, 2016). Walau dalam proses pembelajaran siswa tidak turun ke lapangan, namun guru mampu menghadirkan informasi terkait lingkungan sekitarnya (Harun, 2008) dengan menghadirkan bahan ajar berbasis potensi lokal daerah.

Menghadapi pergeseran paradigma pendidikan Abad 21 (BNSP, 2010) merumuskan prinsip pembelajaran abad 21. Salah satunya perubahan pemikiran dari berpikir faktual menjadi berpikir kritis. Sejalan dengan itu (Lai, 2011) menyatakan salah satu kecakapan hidup yang harus dimiliki siswa pada Abad 21 adalah kecakapan berpikir kritis. Melihat mutu lulusan nasional yang belum menunjukkan kemampuan berpikir kritis (Mukminan, 2014) maka perlu adanya model pembelajaran yang mampu meningkatkan kemampuan berpikir kritis siswa. Kemampuan berpikir kritis dapat ditingkatkan melalui model pembelajaran aktif (Nuryati, Diantoro, \& Zubaidah, 2018), salah satunya dengan model pembelajaran inkuiri terbimbing. Model pembelajaran inkuiri mampu meningkatkan kemampuan berpikir kritis siswa karena domain model pembelajaran inkuiri adalah kemampuan berpikir kritis (Cleverly, 2003), dan penggunaan perangkat pembelajaran inkuiri terbimbing dapat meningkatan keterampilan berpikir kritis (Dahlia, 2017). 
Hasil analisis kebutuhan yang dilakukan di SMPN 2 Paiton menunjukkan bahwa buku teks IPA yang mereka miliki belum mengangkat potensi lokal daerah sebagai sumber belajar. Siswa berharap adanya bahan ajar yang mengangkat potensi lokal hutan mangrove Pantai Duta Paiton sebagai sumber belajar materi ekosistem dan pencemaran lingkungan, serta bahan ajar yang diharapkan dalam bentuk handout berbasis potensi lokal hutan mangrove Pantai Duta Paiton. Sebagian besar siswa juga berharap dapat melakukan pengamatan langsung ke lokasi hutan mangrove Pantai Duta Paiton karena selama ini belum pernah dilakukan pembelajaran di luar kelas. Berdasarkan uraian diatas, tujuan penelitian pengembangan ini untuk menghasilkan perangkat pembelajaran inkuiri terbimbing pada materi ekosistem dan pencemaran lingkungan berbantuan handout berbasis potensi lokal hutan mangrove Pantai Duta Paiton untuk meningkatkan kemampuan berpikir kritis dan sikap peduli lingkungan siswa kelas VII SMPN 2 Paiton.

\section{METODE}

Penelitian pengembangan ini menggunakan model pengembangan ADDIE yang terdiri dari lima tahap, yaitu analyze, design, develop, implement, dan evaluate (Branch, 2009). Penelitian dilaksanakan pada bulan Mei 2019 di SMPN 2 Paiton. Sampel penelitian sebanyak 64 siswa dari kelas VII. Pemilihan sampel dilakukan dengan teknik purposive sampling. Kelas eksperimen dengan jumlah siswa 32 orang akan mengikuti pembelajaran menggunakan perangkat pembelajaran inkuiri terbimbing dipadu handout ekosistem hutan mangrove Pantai Duta Paiton, sedangkan kelas kontrol dengan jumlah siswa 32 orang mengikuti pembelajaran dengan model konvensional. Data diperolah dari hasil validasi, uji kepraktisan, dan uji keefektifan. Uji validasi dilakukan terhadap perangkat pembelajaran inkuiri terbimbing, yaitu silabus, RPP, handout, LKS, dan soal kemampuan berpikir kritis. Uji kepraktisan dilakukan dengan uji keterbacaan handout dan LKS yang dilakukan oleh kelompok kecil, terdiri dari 10 siswa yang telah mengikuti materi ekosistem dan pencemaran lingkungan. Uji kepraktisan dilakukan dengan memberikan tes soal kemampuan berpikir krits serta pemberian angket sikap peduli lingkungan.

\section{HASIL}

Penelitian pengembangan ini menghasilkan produk berupa perangkat pembelajaran inkuiri terbimbing, yaitu silabus, RPP, handout, dan LKS. Produk pengembangan diterapkan pada materi ekosistem dan pencemaran lingkungan kelas VII SMP Semester II. Perangkat pembelajaran yang dibuat mengikuti sintaks model pembelajaran inkuiri terbimbing, yaitu mengeksplorasi fenomena, memfokuskan pada pertanyaan, merancang investigasi, melakukan investigasi, menganalisis data dan bukti, mengkonstruk pengetahuan baru, dan mengkomunikasikan pengetahuan baru (Llewelyn, 2013). Perangkat pembelajaran tersebut terintegrasi kemampuan berpikir kritis (Greenstein, 2012) antara lain apply, evaluate, use data to develop critical insight, analyze, dan synthesize. Selain itu, handout yang dihasilkan berdasarkan hasil eksplorasi hutan mangrove Pantai Duta Paiton yang di dalamnya terintegrasi indikator sikap peduli lingkungan di antaranya mensyukuri ciptaan Tuhan berupa menjaga kelestarian lingkungan, menghayati nilai ajaran agama tentang kelestarian lingkungan, menanggapi bahaya permasalahan lingkungan, mengubah perilaku untuk tidak merusak lingkungan, mengajak untuk memelihara kelestarian lingkungan, menunjukkan sikap peduli terhadap permasalahan lingkungan, mengatasi permasalahan lingkungan, memilih untuk memperhatikan permasalahan lingkungan, mengurangi dampak permasalahan lingkungan, dan berpendapat secara ilmiah dan kritis dalam menyikapi permasalahan lingkungan.

Data hasil penelitian yang diperoleh berupa data kualitatif maupun data kuantitatif. Data kualitatif berupa saran serta masukan dari validator, praktisi lapangan, maupun siswa untuk perbaikan produk yang dikembangkan. Data kuantitatif berasal dari skor kevalidan produk, skor uji kepraktisan, dan skor keefektifan produk.

\section{Data Uji Validitas}

Uji validitas perangkat pembelajaran inkuiri terbimbing dilakukan oleh tiga validator yaitu validator ahli pendidikan, validator ahli materi dan praktisi lapangan. Hasil validasi silabus (Tabel 1) menunjukkan rerata nilai 98,3\% dengan kategori valid, silabus dapat digunakan tanpa revisi. Hasil validasi RPP dengan rerata nilai 97,8\% kategori valid, RPP dapat digunakan tanpa revisi (Tabel 2). Hasil validasi handout dengan rerata nilai 94,3\% kategori valid, handout dapat digunakan tanpa revisi (Tabel 3). Hasil validasi LKS (Tabel 4) dengan rerata nilai 96,4\% kategori valid, LKS dapat digunakan tanpa revisi. Hasil validasi soal kemampuan berpikir kritis (Tabel 5) menunjukkan rerata nilai 97,4\% dengan kategori valid dan dapat digunakan tanpa revisi.

Tabel 1. Hasil Validasi Silabus

\begin{tabular}{clccc}
\hline No. & Validator & Nilai Validasi Silabus (\%) & Rerata (\%) & Kategori \\
\hline 1. & Ahli Pendidikan & 98,9 & & \\
2. & Ahli Materi & 98,5 & 98,3 & Valid \\
3. & Praktisi Lapangan & 97,5 & & \\
\hline
\end{tabular}


Tabel 2. Hasil Validasi RPP

\begin{tabular}{clccc}
\hline No. & \multicolumn{1}{c}{ Validator } & Nilai Validasi RPP $(\%)$ & Rerata $(\%)$ & Kategori \\
\hline 1. & Ahli Pendidikan & 98,7 & & \\
2. & Ahli Materi & 96,6 & 97,8 & Valid \\
3. & Praktisi Lapangan & 98 & & \\
\hline
\end{tabular}

Tabel 3. Hasil Validasi Handout

\begin{tabular}{clccc}
\hline No. & \multicolumn{1}{c}{ Validator } & Nilai Validasi Handout (\%) & Rerata (\%) & Kategori (\%) \\
\hline 1. & Ahli Pendidikan & 98,4 & & \\
2. & Ahli Materi & 84,6 & 94,3 & Valid \\
3. & Praktisi Lapangan & 100 & & \\
\hline
\end{tabular}

Tabel 4. Hasil Validasi LKS

\begin{tabular}{clccc}
\hline No. & \multicolumn{1}{c}{ Validator } & Nilai Validasi LKS (\%) & Rerata (\%) & Kategori \\
\hline 1. & Ahli Pendidikan & 100 & & \\
2. & Ahli Materi & 90,6 & 96,4 & Valid \\
3. & Praktisi Lapangan & 98,6 & & \\
\hline
\end{tabular}

Tabel 5. Rerata Hasil Validasi Soal Kemampuan Berpikir Kritis

\begin{tabular}{clccc}
\hline No. & Validator & Nilai Validasi Kemampuan Berpikir kritis (\%) & Rerata (\%) & Kategori \\
\hline 1. & Ahli Pendidikan & 100 & & \\
2. & Ahli Materi & 95,6 & 97,4 & Valid \\
3. & Praktisi Lapangan & 96,7 & & \\
\hline
\end{tabular}

Penentuan perangkat pembelajaran yang di validasi valid atau tidak dengan cara membandingkan hasil rerata nilai validasi dengan kriteria kevalidan Akbar (2013). Rerata nilai 85,01-100,00\% masuk dalam kategori valid, produk dapat digunakan tanpa revisi.

\section{Data Uji Kepraktisan}

Uji kepraktisan dilakukan untuk mengetahui nilai kepraktisan dari produk yang dikembangkan, yaitu kepraktisan handout dan LKS. Uji kepraktisan dilakukan dengan cara uji keterbacaan oleh kelompok kecil yang terdiri dari 10 siswa yang sudah pernah mendapatkan materi ekosistem dan pencemaran lingkungan. Hasil uji keterbacaan menunjukkan nilai $100 \%$ untuk handout (Tabel 6) dan 99,6\% untuk LKS (Tabel 7) denga kategori valid dan dapat digunakan tanpa revisi.

\section{Tabel 6. Hasil Uji Kepraktisan Handout}

\begin{tabular}{clc}
\hline No. & \multicolumn{1}{c}{ Indikator Penilaian } & Nilai $\mathbf{( \% )}$ \\
\hline 1. & Komponen-komponen dalam Handout & 100 \\
2. & Kebahasaan & 100 \\
3. & Penyajian & 100 \\
4. & Tampilan & 100 \\
5. & Menarik & 100 \\
\hline Rerata Seluruh Indikator (\%) & 100 \\
Kategori & Valid \\
\hline
\end{tabular}

Tabel 7. Hasil Uji Kepraktisan LKS

\begin{tabular}{clc}
\hline No. & Indikator Penilaian & Nilai $(\boldsymbol{\%})$ \\
\hline 1. & Komponen-komponen dalam LKS & 98,7 \\
2. & Kebahasaan & 99,5 \\
3. & Penyajian & 100 \\
4. & Tampilan & 100 \\
5. & Manfaat & 100 \\
\hline Rerata Seluruh Indikator $(\%)$ & 99,6 \\
Kategori & Valid \\
\hline
\end{tabular}

Handout dan LKS yang dihasilkan masuk kategori valid dan dapat digunakan tanpa revisi karena berdasarkan kriteria kepraktisan, nilai antara 85,01-100\% masuk kategori valid dan produk dapat digunakan tanpa revisi (Akbar, 2013). 


\section{Data Uji Keefektifan}

Uji keefektifan dilakukan untuk mengetahui efektif tidaknya produk yang dikembangkan. Produk yang dikembangkan adalah perangkat pembelajaran inkuiri terbimbing serta instrumen penilaian, dan dilihat pengaruhnya terhadap kemampuan berpikir kritis dan sikap peduli lingkungan siswa. Cara mengetahui keefektifan produk adalah dengan memberikan tes soal kemampuan berpikir kritis serta pemberian angket sikap peduli lingkungan. Kelas eksperimen mengikuti pembelajaran dengan menggunakan perangkat pembelajaran inkuiri terbimbing dipadu handout ekosistem berbasis potensi lokal hutan mangrove Pantai Duta Paiton, sedangkan kelas kontrol mengikuti pembelajaran dengan model konvensional. Pemberian tes dan angket dilakukan 2x sebelum pembelajaran dilakukan serta di akhir pembelajaran. Skor maksimal untuk soal berpikir kritis adalah 4, dengan penjabaran skor 1 untuk tingkat novice (pemula), skor 2 untuk basic (dasar), skor 3 untuk proficient (ahli), dan skor 4 untuk exemplary (teladan). Hasil tes maupun angket kemudian di analisis Anakova.

Rerata nilai tes berpikir kritis kelas eksperimen yaitu 32,6 lebih tinggi dari rerata nilai tes berpikir kritis kelas kontrol yaitu 26 (Tabel 8). Hal itu membuktikan bahwa kelas eksperimen secara signifikan mengalami pengaruh lebih tinggi dalam berpikir kritis dibanding kelas kontrol. Artinya penerapan perangkat pembelajarn inkuiri terbimbing dipadu handout ekosistem hutan mangrove Pantai Duta Paiton berpengaruh terhadap kemampuan berpikir kritis siswa.

Tabel 8. Hasil Tes Berpikir Kritis Kelas Eksperimen dan Kelas Kontrol

\begin{tabular}{lccccc}
\hline \multicolumn{1}{c}{ Metode } & Pretes & Postes & Selisih & Peningkatan $(\%)$ & Rerata Terkoreksi \\
\hline Eksperimen & 15,3 & 33,7 & 18,4 & 120 & 32,6 \\
Kontrol & 8,8 & 24,9 & 16,2 & 184 & 26 \\
\hline
\end{tabular}

Rerata nilai sikap peduli lingkungan kelas eksperimen dengan nilai 91,8 lebih tinggi dari rerata nilai sikap peduli lingkungan kelas kontrol yaitu 79,7 (Tabel 9). Hal ini membuktikan kelas eksperimen memiliki sikap peduli lingkungan yang secara signifikan lebih tinggi daripada kelas kontrol. Artinya, terdapat pengaruh penerapan perangkat pembelajaran inkuiri terbimbing dipadu handout berbasis potensi lokal hutan mangrove Pantai Duta Paiton terhadap sikap peduli lingkungan siswa.

Tabel 9. Hasil Angket Sikap Peduli Lingkungan Kelas Eksperimen dan Kelas Kontrol

\begin{tabular}{lccccc}
\hline Kelas & Pretes & Postes & Selisih & Peningkatan $(\%)$ & Rerata Terkoreksi \\
\hline Eksperimen & 72,9 & 92,9 & 20 & 27,5 & 91,8 \\
Kontrol & 69,2 & 78,6 & 9,3 & 13,5 & 79,7 \\
\hline
\end{tabular}

Hasil analisis Anakova yang dilakukan menunjukkan adanya pengaruh penerapan perangkat pembelajaran inkuiri terbimbing dipadu handout berbasis potensi lokal hutan mangrove Pantai Duta Paiton terhadap kemampuan berpikir kritis dan sikap peduli lingkungan.

\section{PEMBAHASAN}

Produk yang dihasilkan penelitian pengembangan ini adalah perangkat pembelajaran inkuiri terbimbing berupa silabus, RPP, handout, LKS, dan instrumen penilaian. Perangkat pembelajaran tersebut di uji validitas, kepraktisan, dan keefektifannya. Uji validitas dilakukan oleh tiga validator, yaitu validator ahli pendidikan, validator ahli materi, dan praktisi lapangan. Hasil validasi silabus adalah 98,3\%, RPP 97,8\%, handout 94,3\%, LKS 96,4\%, dan soal kemampuan berpikir kritis 97,6\%. Hasil validasi perangkat pembelajaran oleh ketiga validator menunjukkan hasil valid dengan keterangan perangkat dapat digunakan tanpa revisi. Kriteria kevalidan dan kepraktisan menggunakan kriteria penilaian (Akbar, 2013). Uji kepraktisan dilakukan dengan menggunakan uji keterbacaan oleh kelompok kecil yang terdiri dari 10 siswa yang pernah mendapatkan materi ekosistem dan pencemaran lingkungan. Hasil uji keterbacaan menunjukkan handout yang dihasilkan valid dengan nilai 100\%, begitu pula dengan LKS dengan nilai 99,6\%. Uji keefektifan produk pengembangan perangkat pembelajaran inkuiri terbimbing dipadu handout ekosistem hutan mangrove Pantai Duta Paiton dilakukan dengan memberikan tes soal kemampuan berpikir kritis serta pemberian angket sikap peduli lingkungan. Hasil analisis kemampuan berpikir kritis menunjukkan rerata nilai kelas eksperimen yang menggunakan perangkat pembelajaran inkuiri terbimbing dipadu handout berbasis potensi lokal hutan mangrove Pantai Duta Paiton memiliki kelas kontrol yang menggunakan pembelajaran konvensional $(32,6>26)$. Begitu pula untuk nilai sikap peduli lingkungan pada kelas eksperimen yang menggunakan perangkat pembelajaran inkuiri terbimbing dipadu dengan handout berbasis potensi lokal hutan mangrove Pantai Duta Paiton memiliki rerata nilai lebih tinggi daripada kelas kontrol yang menggunakan model pembelajaran konvensional $(91,8>79,7)$. Hal ini membuktikan bahwa perangkat pembelajaran inkuiri terbimbing dipadu handout ekosistem hutan mangrove rerata nilai lebih tinggi daripada Pantai Duta Paiton yang dikembangkan oleh peneliti terbukti efektif meningkatkan kemampuan berpikir ktitis serta sikap peduli lingkungan pada siswa.

Pembelajaran inkuiri terbimbing terbukti meningkatkan kemampuan berpikir kritis. Hal ini dikarenakan langkah-langkah dalam model pembelajaran inkuiri mendorong siswa untuk meningkatkan kecakapan berpikir (Arsa, 2015), menstimulasi siswa mendapatkan ide untuk memecahkan masalah yang ditemukan (Falensia, 2019). Model pembelajaran inkuiri menuntut siswa melakukan serangkaian investigasi, eksplorasi, pencarian, eksperimen, penelusuran, dan penelitian (Abidin, 2014). Inkuiri 
melibatkan siswa untuk berpikir dan mengajukan pertanyaan (Coffman, 2009) dan mendorong siswa untuk berpikir kritis (Cleverly, 2003). Sejalan dengan penelitian yang dilakukan oleh Dahlia (2017) yang menyatakan bahwa pembelajaran inkuiri terbimbing mampu meningkatkan kemampuan berpikir kritis.

Angket sikap peduli lingkungan dikembangkan dari 10 indikator sikap peduli lingkungan. Pengembangan instrumen penilaian sikap peduli lingkungan dilakukan agar sesuai dengan tuntutan perkembangan pendidikan (Nufus \& Gani, 2017). Hasil penelitian menunjukkan model pembelajaran inkuiri terbimbing yang dipadu dengan handout ekosistem hutan mangrove Pantai Duta mampu meningkatkan sikap peduli lingkungan pada siswa, sejalan dengan penelitian yang dilakukan oleh Annisha (2018). Hal ini terjadi karena dalam pembelajaran serta handout ekosistem hutan mengrove Pantai Duta terintegrasi indikator sikap peduli lingkungan. Penelitian yang dilakukan Ratnasari, Endang, \& Maknun (2015) menyimpulkan bahwa penerapan model inkuiri terbimbing dapat meningkatkan sikap peduli lingkungan. Model inkuiri efektif menumbuhkan sikap peduli lingkungan karena setiap tahap pembelajaran inkuiri memunculkan sikap ilmiah, peka terhadap lingkungan (Febriana, Ibrohim, \& Mahanal, 2016).

\section{SIMPULAN}

Berdasarkan penelitian yang telah dilakukan, dapat diperoleh simpulan bahwa telah dihasilkan perangkat pembelajaran inkuiri terbimbing berbasis potensi lokal hutan mangrove Pantai Duta Paiton yang terdiri dari silabus, RPP, handout, LKS, dan instrumen penilaian yang valid dan praktis. Hal ini dapat dilihat dari hasil uji validasi dan uji kepraktisan. Serta perangkat pembelajaran inkuiri terbimbing berbasis potensi lokal hutan mangrove Pantai Duta efektif meningkatkan kemampuan berpikir kritis dan sikap peduli lingkungan pada siswa. Beberapa saran yang diberikan antara lain pengembangan perangkat pembelajaran menggunakan model pembelajaran lain yang disesuaikan dengan kompetensi dasar yang hendak dicapai, mengangkat potensi lokal lain sebagai sumber belajar agar siswa memiliki wawasan lebih luas terhadap potensi lokal daerahnya, dan mengembangkan perangkat pembelajaran untuk materi lain selain materi ekosistem dan pencemaran lingkungan.

\section{DAFTAR RUJUKAN}

Annisha, D. (2018). Pengembangan Pembelajaran Inkuiri Terbimbing Berbasis Potensi Lokal Pantai Lhoksemawe dan Pengaruhnya terhadap Keterampilan Berpikir Kritis, Penmahaman Konsep, dan Sikap Peduli Lingkungan Siswa SMK Negeri 6 Perikanan dan Kelautan. Tesis tidak diterbitkan. Universitas Negeri Malang, Malang.

Arsa, I. P. (2015). Belajar dan Pembelajaran Strategi Belajar yang Menyenangkan. Yogyakarta: Media Akademia.

Badan Standar Nasional. (2010). Paradigma Pendidikan Nasional di Abad 21. Jakarta.

Branch, R. M. (n.d.). Instructional Design: The ADDIE Approach. New York: Springer.

Cleverly, D. (2003). Implementing Inquiry-Based Learning in Nursing. London: Routledge.

Coffman, T. (2009). Engaging Students Through Inquiry-Oriented Learning and Technology. New York: Rowman \& Littlefield Education.

Dahlia. (2017). Pengembangan Pembelajaran Interaksi Makhluk Hidup dengan Lingkungan Menggunakan Inkuiri Terbimbing Bersumber Belajar Hutan Wisata Baning Kalbar untuk Meningkatkan Penguasaan Konsep, Keterampilan Berpikir Kritis dan Sikap Ilmiah Siswa SMP. Tesis tidak diterbitkan. Universitas Negeri Malang, Malang.

Falensia, A. (2019). Keterampilan Berpikir Kritis dan Hasil Belajar Siswa Melalui Penerapan Model Pembelajaran Inkuiri Terbimbing pada Mata Pelajaran Bilogi Siswa Kelas XI IPA SMA Negeri 2 Probolinggo Tahun Ajaran 2018/2019. Tesis tidak diterbitkan. Universitas Negeri Malang, Malang.

Faridah. (2012). Pembelajaran Berdasarkan Pendekatan Kontekstual. Sulawesi Selatan: Lembaga Penjaminan Mutu Pendidikan.

Febriana, I., Ibrohim., \& Mahanal, S. (2016). Potensi Pembelajaran Inkuiri dalam Menumbuhkan Sikap Siswa terhadap Lingkungan. Prosiding Semnas Pendidikan IPA Pascasarjana UM, 959-969. Malang: Pascasarjana UM.

Greenstein, L. (2012). Assessing 21st Century Skills: A guide To Evaluating Mastery And Authentic Learning. United Kingdom: SAGE Publications Ltd.

Harun. (2008). Pengertian Pendekatan dan Metode. Direktori File UPI, 1-11.

Hatimah, I. (2006). Pengelolaan Pembelajaran Berbasis Potensi Lokal di. Mimbar Pendidikan, 25(1), 39-45.

Llewelyn, D. (2013). Implementing Inquiry and Argument Based Science Standards in Grade 3-8, Third Edition. USA: Corwin A Sage Company.

Mukminan. (2014). (Mari wes) Tantangan Pendidikan di Abad 21 Peningkatan Kualitas Pembelajaran Pendayagunaan Teknologi Pendidikan. Seminar Nasional Teknologi Pendidikan, 1-11.

Mulyasa, E. (2009). Implementasi Kurikulum Tingkat Satuan Pendidikan. Jakarta: Bumi Aksara.

Mulyasa, E. (2013). Pengembangan dan Implikasi Kurikulum 2013. Bandung: PT Remaja Rosdakarya.

Nufus, S. H., \& Gani, A., S. (2017). Pengembangan Instrumen Sikap Berbasis Kurikulum 2013 pada Pembelajaran Kimia SMA. Jurnal Pendidikan Sains Indonesia, 5(1), 44-51.

Nuryati, L., Diantoro, M., \& Zubaidah, S. (2018). Analisis Kemampuan Berpikir Kritis Siswa SMP. Jurnal Penelitian dan Pengembangan, 3(2), 155-158. https://doi.org/10.23971/eds.v5i2.732 
379 Jurnal Pendidikan, Vol. 5, No. 3, Bln Maret, Thn 2020, Hal 374-379

Peraturan Menteri Pendidikan dan Kebudayaan No 65 tentang Standar Proses Pendidikan Dasar dan Menengah. (2016). Jakarta.

Ratnasari., Endang, A., \& Maknun, D. (2015). Penerapan Model Pembelajaran Inkuiri Terbimbing (Guided Inquiry) untuk Meningkatkan Sikap Peduli terhadap Lingkungan pada Konsep Pencemaran Lingkungan di Kelas VII SMPN 3 Sumber. Scientiae Educatia: Jurnal Pendidikan Sains, 4(2), 1-9.

Sanjaya, A. (2013). Instrumen Perangkat Pembelajaran. Bandung: PT Remaja Rosdakarya.

Sanjaya, W. (2010). Strategi Pembelajaran Berorientasi Standar Proses Pendidikan. Jakarta: Kencana Prenamedia Group.

Situmorang, R. P. (2016). Analisis Potensi untuk Mengembangkan Bahan Ajar Biologi di SMA Negeri 2 Wonosari. Jurnal Pendidikan Sains, 4(1), 51-57. 